\title{
Calcium effect and pH-dependence on self-association and structural stability of the Apis mellifera major royal jelly protein 1
}

\author{
Gabriel C. N. Cruz ${ }^{1}$, Liudy Garcia ${ }^{2}$, Adelson J. Silva ${ }^{4}$, João A. R. G. Barbosa ${ }^{3}$, \\ Carlos A. O. Ricart ${ }^{1}$, Sonia M. Freitas ${ }^{4}$, Marcelo V. Sousa ${ }^{1}$ \\ ${ }^{1}$ Brazilian Center for Protein Research, Department of Cell Biology, University of Brasilia (UnB), Brasilia, DF, \\ Brazil \\ ${ }^{2}$ Mass Spectrometry Group, Physics Department, CEADEN, Havana, Cuba \\ ${ }^{3}$ Center for Structural Molecular Biology (CeBiME), Brazilian Synchrotron Light Laboratory (LNLS), Campinas, \\ SP, Brazil \\ ${ }^{4}$ Laboratory of Biophysics, Department of Cell Biology, University of Brasilia (UnB), Brasilia, DF, Brazil
}

Received 4 November 2009 - Revised 18 March 2010 - Accepted 25 March 2010

\begin{abstract}
The major royal jelly protein 1 (MRJP1) is the main glycoprotein in honey bee royal jelly. In brain tissues, MRJP1 is found in intercellular spaces and associated to cytoskeleton within cells. MRJP1 must be involved in multiple biological functions, yet there is a lack of structural information on the protein. MRJP1 was herein purified from royal jelly and characterized through electrophoresis and mass spectrometry as the same protein found in cerebral tissue. Unfolding curves obtained by circular dichroism analyses strongly suggest its high stability under different $\mathrm{pHs}$. However, calcium ions made MRJP1 susceptible to temperature and $\mathrm{pH}$ effects. In the presence of $2 \mathrm{mM}$ calcium, very high stabilities were achieved at $\mathrm{pH} 6.0$ and 7.0 with $\Delta G^{25}$ over $62 \mathrm{~kJ} \mathrm{~mol}^{-1}$. Overall, the present results represent a valuable effort aimed at the structural characterization of MRJP1, representing an essential step toward the determination of its roles in honey bee neural processes.
\end{abstract}

MRJP1 / Apis mellifera / protein stability / mass spectrometry / circular dichroism

\section{INTRODUCTION}

The honey bee (Apis mellifera) is a social insect that presents complex behaviors and is able to execute multiple tasks (Page and Peng 2001; Menzel et al. 2006). It has long been acknowledged for their crucial function in plant pollination in natural environments as well as in agricultural crops.

Royal jelly is produced in the cephalic glands of both nurse and forager worker bee subcastes.

Corresponding author: S.M. Freitas, nina@unb.br

Manuscript editor: Klaus Hartfelder
It is the main food for larvae, and is imperative for caste differentiation from larvae to queen (Winston 1987; Ohashi et al. 1997). This is a case of insect polyphenism regulated by differential nourishment (Evans and Wheeler 2001; Malecova et al. 2003). Royal jelly is fed to honey bee larvae, but is provided to the queen throughout its whole lifespan, and sustains its high reproductive ability (Ohashi et al. 1997).

A large family of major royal jelly proteins (MRJPs) is present in this secretion. MRJPs are similar to yellow proteins from Drosophila melanogaster and other insects as well as to putative proteins from bacteria (Albert and Klaudiny 2004; Drapeau et al. 2006). Little is 
known about biological functions of such a class of proteins, but some suggestions have been proposed like sex-specific reproductive maturation (Drapeau et al. 2006) and developmental processes in bee nervous system (Peixoto et al. 2009). They are linked to queen development by still unclear mechanisms (Albert and Klaudiny 2004; Consortium, 2006). In addition, they are believed to exert defensive functions against fungi and bacteria, as assigned in the Gene Ontology database. Finally, a structural motif of dopachrome-conversion enzyme is apparently present along some MRJPs sequences, as found in some yellow proteins (Futahashi et al. 2008).

The most abundant protein in royal jelly is MRJP1 (major royal jelly protein 1) (Scarselli et al. 2005) that is encoded by a single gene and composed of 413 amino acids in its processed form (Malecova et al. 2003; Drapeau et al. 2006). It appears to be posttranslationally modified at different extents and displays at least eight isoforms with similar isoelectric points $(\mathrm{p} I)$ when separated by isoelectric focusing (Hanes and Simuth 1992). This was suggested to be caused by polymorphisms with some amino acid substitutions and/or by genetic variability of honey bee individuals in the hive (Schmitzova et al. 1998).

MRJP1 is a $55-57 \mathrm{kDa}$ protein as determined by gel electrophoresis, but goes down to $47 \mathrm{kDa}$ after treatment with N-glycosidase F (Ohashi et al. 1997), in agreement to the theoretical mass calculated for MRJP1 without the signal peptide (19 N-terminal residues) (Schmitzova et al. 1998). Three MRJP1 hypothetical glycosylation sites have been proposed based on its primary structure (Ohashi et al. 1997). Another interesting feature of MRJPl is that it is present in monomeric and oligomeric forms in royal jelly (Simuth 2001; Tamura et al. 2009a).

Several changes at structural and proteomic levels are observed during the ontogenetic differentiation from nurse to forager worker subcastes (Fahrbach and Robinson 1995; Wolschin and Amdam 2007; Garcia et al. 2009). Recently, we showed by two-dimensional electrophoresis and proteome analysis that MRJP1 is the most abundant protein in the nurse brain, suffering downregulation toward forager brain during the differentiation process (Garcia et al. 2009). In addition, it was immunolocalized in intercellular spaces between cells in mushrooms bodies (presumed centers of learning and memory in the honey bee brain), indicating that it is a secreted protein (Garcia et al. 2009). However, MRJP1 was also detected in the cytoplasm of brain cells of the antennal lobe, optical lobe and mushroom body (Garcia et al. 2009; Peixoto et al. 2009), which is an indication of the multiple functions associated to this protein. Additionally, it was deposited on the rhabdom, a structure of the retinular cells composed of numerous tubules, suggesting its association to proteins of filamentous structures such as cytoskeleton (Garcia et al. 2009). (Kucharski et al. 1998) had previously found the mRNA for this protein in the mushroom bodies of $A$. mellifera brain, concentrated in a defined population of Kenyon cells.

Therefore, besides the nutritional role in royal jelly, MRJP1 is thought to have other possible unknown functions in the neural tissue, that possibly appeared during the evolution of sociality (Albert et al. 1999; Consortium, 2006). Ontological bioinformatics analysis suggested that MRJP1 is potentially involved in developmental processes in the A. mellifera nervous system (Peixoto et al. 2009). Diverse biological activities have been reported for MRJP1. It shows growth stimulation of human lymphocytes in a serumfree medium (Watanabe et al. 1998), enhancement of cell proliferation in rat hepatocytes (Kamakura et al. 2001c), antifatigue effect in mice (Kamakura et al. 2001b), stimulation of TNF- $\alpha$ release by mouse macrophages, and possible roles in cytokine-induced activation of genes important for immune response of honey bees and humans (Simuth et al. 2004; Majtan et al. 2006).

Despite the knowledge gathered about MRJP1, there is still a lack of structural information on such intriguing protein. In the present work, MRJP1 was isolated from royal jelly, compared to its honey bee brain counterpart by mass spectrometry, and character- 
ized regarding its structural features by dynamic light scattering and circular dichroism spectroscopy.

\section{MATERIALS AND METHODS}

\subsection{Royal jelly fractionation}

About $250 \mathrm{mg}$ of commercial royal jelly (Apivita, Rio Claro, Brazil) were homogenized in $1.2 \mathrm{~mL}$ of $50 \mathrm{mM}$ Tris- $\mathrm{HCl}$ pH 7.5 (buffer A) containing $10 \mathrm{mM}$ ethylenediaminetetraacetic acid (EDTA) and a cocktail of proteases inhibitors (cOmplete Mini, Roche, Mannheim, Germany). The extract was stirred for $2 \mathrm{~min}$ in vortex and centrifuged at $16,000 \mathrm{~g}$ for $30 \mathrm{~min}$ at room temperature. The soluble material ( $\sim 10 \mu \mathrm{g} / \mu \mathrm{L}$ proteins) was submitted to anionexchange chromatography using a Mono- $Q^{\circledR}$ HR 10/10 column (Pharmacia, Uppsala, Sweden) coupled to a FPLC system. The column $(8 \mathrm{~mL})$ was equilibrated with buffer A under a $1.5 \mathrm{~mL} / \mathrm{min}$ flow. Elution was performed using a $0-1 \mathrm{M} \mathrm{NaCl}$ gradient in buffer A: 0-10 min, buffer A; 10-60 min, 0-0.2 M $\mathrm{NaCl}$; 60-90 min, 0.2-0.5 M NaCl; 90-95 min, 0.5$1 \mathrm{M} \mathrm{NaCl}$; 95-100 min, $1 \mathrm{M} \mathrm{NaCl}$. All solutions were filtered using $0.22 \mu \mathrm{m}$ pores and degassed before use. The chromatographic run was conducted at room temperature, and accompanied by optical absorption at $280 \mathrm{~nm}$. Protein quantification was performed according to Bradford (1976). Collected fractions were analyzed by SDS-PAGE, and those of interest were pooled, dialyzed against distilled water at $4^{\circ} \mathrm{C}$ and lyophilized.

\subsection{Extraction of honey bee brains}

Nurse honey bees (A. mellifera) were acquired from Vereda Rosa Apiaries (Brasilia, Brazil). Bees were anesthetized with chloroform, and brains were dissected and thoroughly washed in cold TBS (20 mM Tris- $\mathrm{HCl} \mathrm{pH} 7.5,150 \mathrm{mM} \mathrm{NaCl}$ ) and then in lysis buffer ( $7 \mathrm{M}$ urea, $2 \mathrm{M}$ thiourea, $85 \mathrm{mM}$ dithiothreitol (DTT), 2.5\% (v/v) Triton X-100, 0.5\% immobilized $\mathrm{pH}$ gradient (IPG) buffer $\mathrm{pH} 4-7$ ) containing a cocktail of protease inhibitors (cOmplete Mini, Roche). Honey bee brain extracts were prepared out of ten pooled through homogenization using a Sample Grinding Kit (GE Healthcare, Uppsala, Sweden) into $200 \mu \mathrm{L}$ of lysis buffer in ice; immediately immersed in liquid nitrogen and stored at $-20^{\circ} \mathrm{C}$. Before use, brain extract was centrifuged by $16,000 \mathrm{~g}, 15 \mathrm{~min}$ at room temperature. Protein quantification of the supernatant was performed using 2-D Quant Kit (GE Healthcare).

\subsection{SDS-PAGE}

Sodium dodecyl sulfate polyacrylamide gel electrophoresis (SDS-PAGE) was carried out at $30 \mathrm{~mA}$ constant current at $10 \% \mathrm{~T}$ polyacrylamide, $1.5 \mathrm{mM}$ thick gel, connected to a cooling bath using a TE2000 (Tecnal, Piracicaba, Brazil) apparatus. Proteins in gel were silver stained according to Blum et al. (1987). Phosphorylase b (97 kDa), bovine serum albumin (66 kDa), egg albumin (45 kDa), carbonic anydrase $(30 \mathrm{kDa})$ and trypsin inhibitor $(20.1 \mathrm{kDa})$ were used as molecular weight markers.

\subsection{Two-dimensional electrophoresis}

Two-dimensional electrophoresis (2-DE) was performed using an Ettan IPGphor 3 system (GE Healthcare) for the first dimension and a Protean II system (BioRad, Hercules, CA, USA) for the second one, both at $20^{\circ} \mathrm{C}$. Proteins were separated by isoelectric focusing (IEF) in $18 \mathrm{~cm}$ IPG strips (GE Healthcare), previously rehydrated for $6 \mathrm{~h}$ in $350 \mu \mathrm{L}$ lysis buffer containing 10\% isopropanol (Garcia et al. 2009). Samples containing $50 \mu \mathrm{g}$ brain extract protein or $10 \mu \mathrm{g}$ purified MRJP1 were separated in 4-7 $\mathrm{pH}$ range under the following conditions: rehydration for $6 \mathrm{~h}, 30 \mathrm{~V}$ for $6 \mathrm{~h}, 500 \mathrm{~V}$ for $1 \mathrm{~h}$, $1,000 \mathrm{~V}$ (gradient) for $1 \mathrm{~h}$ and $8,000 \mathrm{~V}$ (gradient) for $3 \mathrm{~h}$ and $8,000 \mathrm{~V}$ for $1 \mathrm{~h}$ and $40 \mathrm{~min}$ (28,630 total $\mathrm{Vh}$ ). Before the second-dimension step, the IPG gel strips were subjected to reduction and alkylation. Thus, strips were soaked for $20 \mathrm{~min}$ in a solution containing $6 \mathrm{M}$ urea, 30\% (v/v) glycerol, 2\% (w/v) SDS and $125 \mathrm{mM}$ DTT and for additional $20 \mathrm{~min}$ in the same buffer containing $300 \mathrm{mM}$ acrylamide instead of DTT. SDS-PAGE was performed on $10 \% \mathrm{~T}$ polyacrylamide gels, $1.0 \mathrm{mM}$ thick, connected to a cooling bath using the same molecular weight markers and running conditions as described for the SDS-PAGE. Proteins were monitored using a mass 
spectrometry (MS) compatible silver staining procedure (Blum et al. 1987).

\subsection{In situ digestion}

Bands or spots of interest were excised from gel and distained in a freshly prepared $15 \mathrm{mM}$ potassium ferricyanide, $50 \mathrm{mM}$ sodium thiosulfate solution for 10 min (Gharahdaghi et al. 1999). Gel pieces were rinsed two to three times in Milli-Q water (Millipore, Billerica, MA, USA) to stop the reaction; washed three times in water and acetonitrile alternately, 10 min each; and then vacuum dried using a Speed Vac system (Savant, Farmingdale, NY, USA). Samples were subjected to in situ reduction and alkylation. Reduction of disulfide bonds was performed by incubating gel pieces in $100 \mathrm{mM}$ ammonium bicarbonate solution with $10 \mathrm{mM}$ DTT for $1 \mathrm{~h}$ at $56^{\circ} \mathrm{C}$. After removing this solution, cysteine residues were alkylated in $100 \mathrm{mM}$ ammonium bicarbonate solution with $55 \mathrm{mM}$ iodoacetamide for $45 \mathrm{~min}$ at room temperature in the dark. A new washing cycle water/acetonitrile was carried out before drying. Gel slices were then rehydrated in $50 \mathrm{mM}$ ammonium bicarbonate, $5 \mathrm{mM}$ calcium chloride solution containing sequencing grade modified trypsin (Promega, Madison, WI, USA) at $12.5 \mathrm{ng} / \mu \mathrm{L}$ and incubated at $37^{\circ} \mathrm{C}$ overnight. Peptides were extracted twice with $66 \%(v / v)$ acetonitrile, $0.1 \%$ $(v / v)$ trifluoroacetic acid solution by sonication, desalted and concentrated using ZipTips C18 (Millipore, Bedford, MA, USA).

\subsection{Protein identification}

Tryptic digests eluted from the gels were mixed in a matrix solution $(10 \mu \mathrm{g} / \mu \mathrm{L} \alpha$-cyano-4-hydroxycinnamic acid) prepared in 50\% (v/v) acetonitrile, $0.1 \%$ $(v / v)$ trifluoroacetic acid. Each sample was spotted onto the sample plate, and was allowed to dry before matrix-assisted laser desorption/ionization-time of flight (MALDI-TOF) MS analysis. The spectra were collected using an Autoflex II MALDI-TOF/TOF mass spectrometer (Bruker Daltonics, Bremen, Germany) in delayed extraction and reflector modes. External calibration was performed using a peptide standard kit (Bruker Daltonics). Known trypsin autolysis and keratin peaks (842.50 and 1475.77, respectively) were used for the internal calibration. Peptide masses $\left(\mathrm{MH}^{+}\right)$were recorded in 750 to 3,000 Da range. The peptides mass spectra were generated using the software FlexControl v. 2.4 (Bruker Daltonics). The software FlexAnalysis v. 2.4 (Bruker Daltonics) was used to acquire and process the peak lists that were employed for database search using BioTools v. 2.0 (Bruker Daltonics) linked to Mascot (http://www.matrixs cience.com/) (Perkins et al. 1999) against the NCBI protein database (National Center for Biotechnology Information, Bethesda, USA). Monoisotopic masses of tryptic peptides were used to identify the proteins by Peptide Mass Fingerprinting (PMF). Error tolerance for peptide mass was lower than $100 \mathrm{ppm}$ and no restrictions were imposed on protein molecular mass or phylogenetic lineage. Further search parameters were methionine oxidation as variable modification and propionamide cysteine (acrylamide alkylation) or carbamidomethyl cysteine (iodoacetamide alkylation) as fixed modification. Missed cleavages sites were set up to 1 . Hits were considered significant if the protein score exceeded the threshold score calculated by Mascot software assuming $P$ value $<0.05$.

Tandem mass spectra (MS/MS) were also acquired using Autoflex II MALDI-TOF/TOF mass spectrometer (Bruker Daltonics). Parental ions were selected within $2 \%$ parent mass error, and spectra accumulated from 400 laser shots. Fragmentation was then performed using a boost of $150 \%$ in detector gain and of $20 \%$ in laser power after parental spectrum selection. Further processing of the MS/MS spectra were performed using FlexAnalysis v. 2.4. All MS/ MS data from each individual spot were merged into a single file using BioTools v. 2.0 before search. MS/ MS datasets were searched against the protein sequence database using the following parameters: only tryptic peptides with up to one missed cleavage site were allowed; mass tolerances of $100 \mathrm{ppm}$ for MS and 0.5 Da for MS/MS fragment ions; propionamide cysteine as fixed modification and oxidized methionine as variable modification.

\subsection{Dynamic light scattering analysis}

Dynamic light scattering (DLS) provides information about the size, distribution and homogeneity of 
macromolecules in solution, and can be used to monitor protein aggregation. The light scattering measurements by DLS is used to calculate the hydrodynamic radius, which is defined as the radius of a spherical particle with the same diffusion coefficient as the macromolecule of interest. DLS assays were carried out through a laser wavelength of $800 \mathrm{~nm}$, using a DynaPro-LSD model (Wyatt Technology Corporation, Santa Barbara, CA, USA) molecular-sizing instrument equipped with a Peltier system for temperature control, reaching $60^{\circ} \mathrm{C}$. Solutions of MRJP1 were centrifuged at $15,000 \mathrm{~g}$ for $20 \mathrm{~min}$ at $4{ }^{\circ} \mathrm{C}$, and the supernatant filtered through a $0.22 \mu \mathrm{m}$ filter (Millipore) and added to the cuvette. The hydrodynamic parameters were measured at different $\mathrm{pHs}$, temperatures, and concentrations of protein.

The measured intensity of scattered light from each sample was normalized considering the buffer scattering contribution. Polydispersity parameter $(P d)$, averaged hydrodynamic radius $\left(R_{H}\right)$, averaged hydrodynamic diameter $\left(D_{H}\right)$, molecular weight, sum of squares (SOS) were determined from the intensity correlation function using the cumulants method (Frisken 2001; Hassan and Kulshreshtha 2006) and using the Dynamics V.6 software.

\subsection{Circular dichroism spectroscopy}

Circular Dichroism (CD) assays were carried out using Jasco J-815 spectropolarimeter (Jasco, Tokyo, Japan) equipped with a Peltier type temperature controller and thermostatized cuvette cell linked to a thermostatic bath. Far-UV spectra were recorded using 0.1 or $0.2 \mathrm{~cm}$ pathlength quartz cuvettes. MRJP1 $(2.5 \mu \mathrm{M}$ or $5 \mu \mathrm{M})$ was analyzed in different buffer conditions: $2 \mathrm{mM}$ sodium citrate $\mathrm{pH} 3.0,2 \mathrm{mM}$ sodium acetate $\mathrm{pH} 4.0,5.0$ or $6.0,2 \mathrm{mM}$ Hepes $\mathrm{pH} 7.0$ or 8.0 , $2 \mathrm{mM}$ CHES pH 9.0. Four consecutive measurements were accumulated and the mean spectra recorded. Eventual errors due to buffer or instrument effects were discarded by the subtraction of the baseline spectrum from each protein spectrum. Thermal denaturation assays were performed raising the temperature at $0.5^{\circ} \mathrm{C} / \mathrm{min}$, from $20^{\circ} \mathrm{C}$ to $95^{\circ} \mathrm{C}$, unless specified otherwise. The observed ellipticities were converted into molar ellipticity ([$\theta])$ based on molecular mass per residue of $113 \mathrm{Da}$. Protein structure was tracked by changes in $[\theta]$ at $218 \mathrm{~nm}$, where the maximal signal intensity was verified in all conditions at $25^{\circ} \mathrm{C}$.

The unfolded protein fraction $\left(f_{\mathrm{U}}\right)$, the equilibrium constant (Keq) and the Gibbs free energy $\left(\Delta G^{25}\right)$ were calculated using the following equations (Pace et al. 1997):

$f_{\mathrm{U}}=\left(y_{\mathrm{N}}-y\right) /\left(y_{\mathrm{N}}-y_{\mathrm{U}}\right)$

$K_{\mathrm{eq}}=[U] /[N]=f_{\mathrm{U}} /\left(1-f_{\mathrm{U}}\right)$

$\Delta G=-R T \ln K_{e q}$

where $\mathrm{y}_{N}$ and $\mathrm{y}_{U}$ represent the amount of $\mathrm{y}$ protein present in native and unfolded state, respectively. [U] and $[\mathrm{N}]$ denote the protein concentration in unfolded and native state, respectively; $R$, the universal gas constant $\left(8.314 \mathrm{~J} \mathrm{~K}^{-1} \mathrm{~mol}^{-1}\right.$ or $1.987 \mathrm{cal} \mathrm{K}^{-1} \mathrm{~mol}^{-1}$ ) and $T$, the temperature in Kelvin $(\mathrm{K})$. The melting temperature $(\mathrm{Tm})$ where the unfolding occurs was calculated from the $\Delta G$ versus temperature plot. Enthalpy $(\Delta H m)$ and entropy $(\Delta S m)$ parameters were calculated from van't Hoff plot, Eq. 5:

$\Delta G=\Delta H-T \Delta S$

$R \ln K_{\mathrm{eq}}=-\Delta H(1 / T)+\Delta S$

Secondary structure content were estimated from the CD curves adjustments (Böhm 1997) using the CDNN deconvolution software (Version 2.1, Bioinformatik. biochemtech.uni-halle.de/cdnn) considering the database that resulted on total sum of secondary structures closest to $100 \%$.

\section{RESULTS}

\subsection{Purification of the MRJP1}

Royal jelly crude extract was fractionated by anion-exchange chromatography (Figure 1). Two 


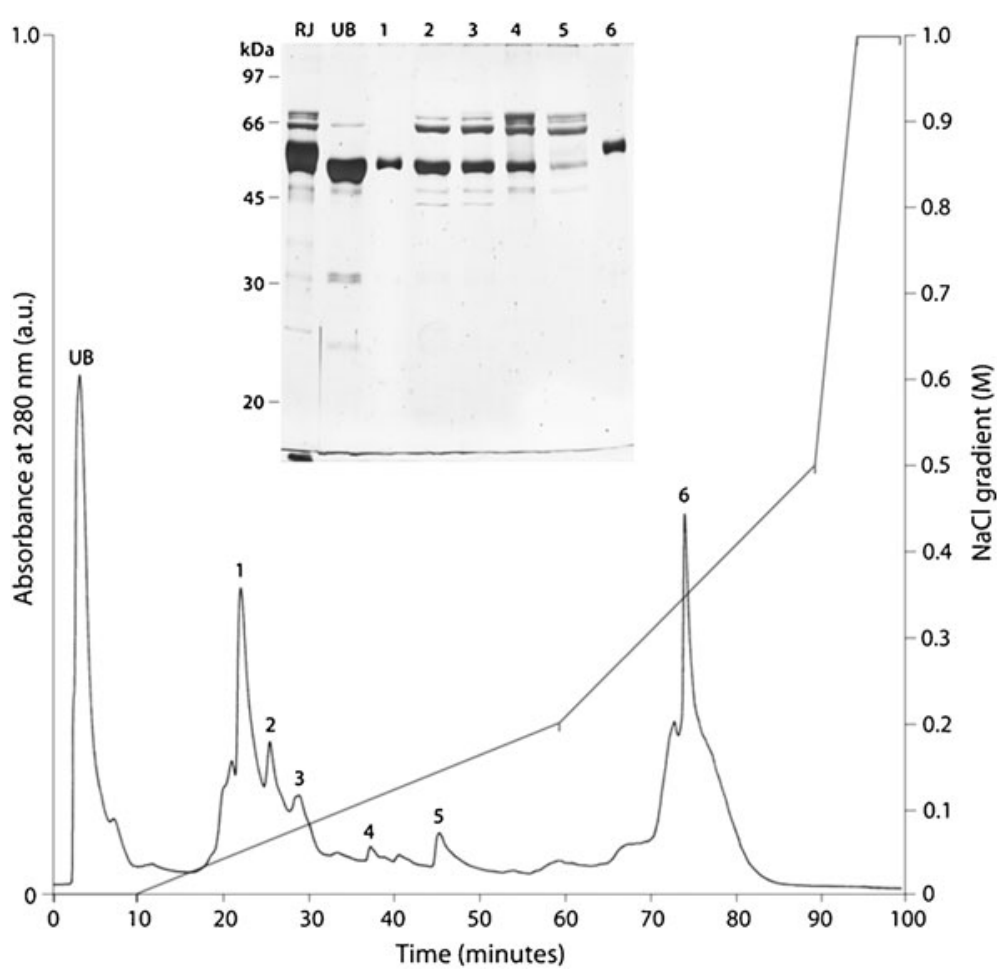

Figure 1. Separation of royal jelly proteins by anion-exchange FPLC. Soluble fraction of royal jelly was submitted to chromatography. Retained proteins were eluted by a $\mathrm{NaCl}$ gradient in $50 \mathrm{mM}$ Tris- $\mathrm{HCl} \mathrm{pH} 7.5$ buffer. Elution was accompanied by absorbance at $280 \mathrm{~nm}$. The main peaks were collected as indicated (1-6). Inset-SDS-PAGE of royal jelly protein fractions. Royal jelly soluble fraction $(R J), 5 \mu \mathrm{g}$, the unbound material $(U B), 5 \mu \mathrm{g}$, and the eluted fractions $1-6,2 \mu \mathrm{g}$, were separated in a $10 \%$ polyacrylamide gel. Molecular weight markers are represented on the left side.

main proteins were collected in the fractions represented by peaks 1 and 6 , respectively. These proteins were eluted with buffer containing 40$60 \mathrm{mM}$ and $300-400 \mathrm{mM} \mathrm{NaCl}$, respectively. No visible contaminants were present in these fractions as showed in silver stained SDSPAGE (Figure 1, inset). The main protein in fraction associated with peak 1 was identified as Major Royal Jelly Protein 2 (MRJP2), and the one associated with peak 6 as Major Royal Jelly Protein 1 (MRJP1) by PMF via MALDI-TOF MS with searches against the NCBI nonredundant protein database using Mascot software (Table I). Additional analysis of MRJP1 by 2DE revealed nine main isoforms (Figure 2) from $\mathrm{p} I 4.7$ to 5.2 (Table II). The protein spots were identified by PMF as MRJP1 from A. mellifera with high scores and sequence coverage (Table II).

\subsection{Comparison between royal jelly and brain MRJP1s}

Nurse honey bee brain proteome was analyzed by 2-DE (Figure 3) to check the overlapping between royal jelly MRJP1 (Figure 2) and brain MRJP1. Previous report had identified the MRJP1 in honey bee brain (Garcia et al. 2009), which was confirmed herein by PMF resulting in a high score of 148, with 19 matched peptides and $43 \%$ sequence coverage. MRJP1 isoforms from both royal jelly and brain 
Table I. Mass spectrometric identification of proteins separated by anion exchange chromatography.

\begin{tabular}{llccccc}
\hline Peak & $\begin{array}{c}\text { Identified } \\
\text { protein }\end{array}$ & $\begin{array}{c}\text { Organism/Protein } \\
\text { ID }\end{array}$ & $\begin{array}{c}\text { Score } \\
\text { mascot }\end{array}$ & $\begin{array}{c}\text { Matched } \\
\text { peptides }\end{array}$ & $\begin{array}{l}\text { Coverage } \\
(\%)\end{array}$ & $\begin{array}{l}\text { Mr (kDa) } \\
\text { (Theor./Obs.) }\end{array}$ \\
\hline 1 & $\begin{array}{l}\text { Major royal jelly } \\
\text { protein 2 }\end{array}$ & Apis mellifera/gi|58585108 & 117 & 9 & 23 & $51.041 / 51.3$ \\
6 & $\begin{array}{l}\text { Major royal jelly } \\
\text { protein 1 }\end{array}$ & Apis mellifera/gi|58585098 & 167 & 13 & 39 & $48.855 / 56.0$ \\
\hline
\end{tabular}

were localized on coinciding areas in their respective 2-DE gels (Figures 2 and 3).

Similarity between MRJP1s from the two sources was evaluated comparing MS spectra from royal jelly isoform 6 and a central isoform from brain (Figure 4). Almost all tryptic peptides that matched peptide masses in database searches were actually found in the spectra from both isoforms under MS analysis (Figure 4). Few differences could be detected between peptide masses generated from the MRJP1 primary sequence and peptide masses recorded by MS. The ion at $\mathrm{m} / \mathrm{z} 1614.8$ was more intense in the spectrum from the brain isoform, which corresponds to the ion at $\mathrm{m} / \mathrm{z} 1630.8$ minus a methionine oxidation, only present in the royal jelly isoform spectrum. Isotope overlaps of ions were found at $\mathrm{m} / \mathrm{z} 1631.7$ and 1630.8 from brain and royal jelly isoforms respectively. The ion at $\mathrm{m} / \mathrm{z} 1746.7$ is more abundant in the brain spectrum while its methionine oxidized counterpart at $\mathrm{m} / \mathrm{z} 1762.7$ is richer in the royal jelly isoform spectrum. Considering these results, above mentioned ions $(\mathrm{m} / \mathrm{z}$ 1614.8, 1630.8,

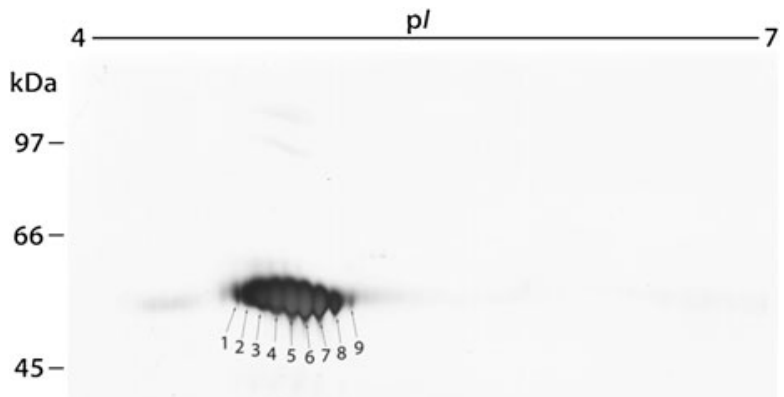

$30-$

$20-$

Figure 2. 2-DE of peak 6 fraction. An amount of $10 \mu \mathrm{g}$ of protein was separated by immobilized $\mathrm{pH}$ gradient (4-7) in the first dimension and 10\% polyacrylamide SDS-PAGE, in the second one. Proteins were silver stained. Arrows indicate protein spots that were identified by PMF as shown in Table II. Molecular weight markers are represented on the left side. 
Table II. Mass spectrometric identification of proteins separated by two-dimensional electrophoresis.

\begin{tabular}{cllccccc}
\hline Spot & $\begin{array}{c}\text { Identified } \\
\text { protein }\end{array}$ & \multicolumn{1}{c}{$\begin{array}{c}\text { Organism/Protein } \\
\text { ID }\end{array}$} & $\begin{array}{c}\text { Score } \\
\text { mascot }\end{array}$ & $\begin{array}{c}\text { Matched } \\
\text { peptides }\end{array}$ & $\begin{array}{l}\text { Coverage } \\
(\%)\end{array}$ & $\begin{array}{l}\text { pI (Theor./ } \\
\text { Obs.) }\end{array}$ & $\begin{array}{c}\text { (Theor./ } \\
\text { Obs.) }\end{array}$ \\
\hline 1 & $\begin{array}{l}\text { Major royal jelly } \\
\text { Protein 1 }\end{array}$ & Apis mellifera/gi|58585098 & 111 & 11 & 37 & $5.10 / 4.72$ & $48.855 / 56.1$ \\
2 & $\begin{array}{l}\text { Major royal jelly } \\
\text { Protein 1 }\end{array}$ & Apis mellifera/gi|58585098 & 155 & 16 & 46 & $5.10 / 4.77$ & $48.855 / 56.1$ \\
3 & $\begin{array}{l}\text { Major royal jelly } \\
\text { Protein 1 }\end{array}$ & Apis mellifera/gi|58585098 & 151 & 16 & 48 & $5.10 / 4.82$ & $48.855 / 56.1$ \\
4 & $\begin{array}{l}\text { Major royal jelly } \\
\text { Protein 1 }\end{array}$ & Apis mellifera/gi|58585098 & 126 & 14 & 43 & $5.10 / 4.88$ & $48.855 / 55.6$ \\
5 & $\begin{array}{l}\text { Major royal jelly } \\
\text { Protein 1 }\end{array}$ & Apis mellifera/gi|58585098 & 141 & 15 & 42 & $5.10 / 4.95$ & $48.855 / 55.0$ \\
6 & $\begin{array}{l}\text { Major royal jelly } \\
\text { Protein 1 }\end{array}$ & Apis mellifera/gi|58585098 & 163 & 17 & 44 & $5.10 / 5.00$ & $48.855 / 54.5$ \\
7 & $\begin{array}{l}\text { Major royal jelly } \\
\text { Protein 1 }\end{array}$ & Apis mellifera/gi|58585098 & 142 & 14 & 42 & $5.10 / 5.05$ & $48.855 / 54.0$ \\
8 & $\begin{array}{l}\text { Major royal jelly } \\
\text { Protein 1 }\end{array}$ & Apis mellifera/gi|58585098 & 145 & 16 & 50 & $5.10 / 5.12$ & $48.855 / 54.0$ \\
9 & $\begin{array}{l}\text { Major royal jelly } \\
\text { Protein 1 }\end{array}$ & Apis mellifera/gi|58585098 & 90 & 9 & 31 & $5.10 / 5.20$ & $48.855 / 54.0$ \\
\hline
\end{tabular}

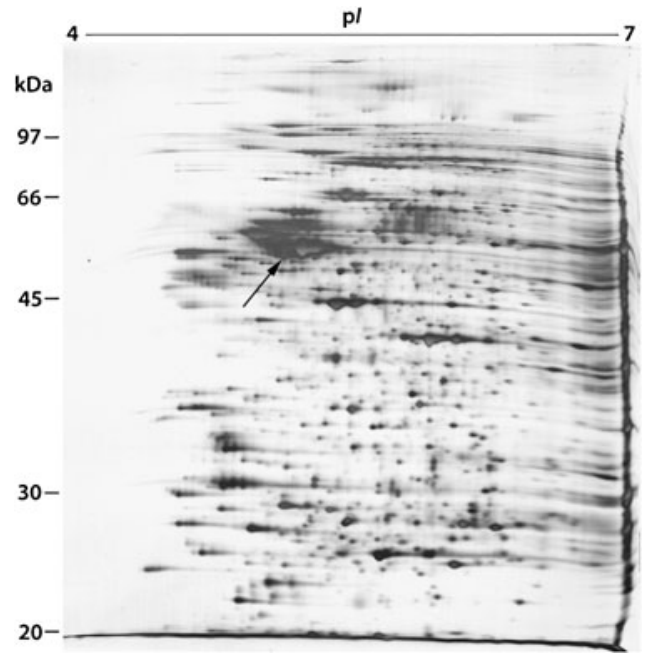

Figure 3. 2-DE of total protein extract from nurse bee brains. $50 \mu \mathrm{g}$ of protein was separated by immobilized $\mathrm{pH}$ gradient (4-7) in the first dimension and $10 \%$ polyacrylamide SDS-PAGE, in the second one. Proteins were silver stained. Arrow indicates the MRJP1 spot that was identified by PMF and compared to the royal jelly MRJP1. Molecular weight markers are represented on the left side.
1746.7 and 1762.7) were submitted to MS/ MS analysis. Their sequence and modifications (methionine oxidation) could then be confirmed by searches over the NCBI database. The ions at $\mathrm{m} / \mathrm{z} 1746.7$ and 1614.8 were identified as the MRJP1 peptides Met388 Arg401 (MVNNDFNFDDVNFR) and Ile402 Arg415 (IMNANVNELILNTR), respectively. Their putatively modified counter-parts at $\mathrm{m} / \mathrm{z}$ 1762.7 and 1630.8 showed the same sequences above, but oxidations in methionines. A missed cleavage after Lys96 resulted in $m / z 2075.1$ in the brain sample. This peptide had one more lysine residue than the ion at $\mathrm{m} / \mathrm{z}$ 1946.9, present in both spectra. The peak at $\mathrm{m} / \mathrm{z}$ 2264.3 in brain represented the $\mathrm{m} / \mathrm{z} 2335.1$ without the alkylation at Cys329. Another missed cleavage after Lys38 generated $\mathrm{m} / \mathrm{z}$ 2501.1 in the royal jelly MRJP1, which could correspond to a larger peptide constituted by the peptides at $\mathrm{m} / \mathrm{z} 1122.5$ and 1397.5.

Other superimposed MRJP1 isoforms from brain and royal jelly were also compared in terms of MS spectra of tryptic digests, similarly 


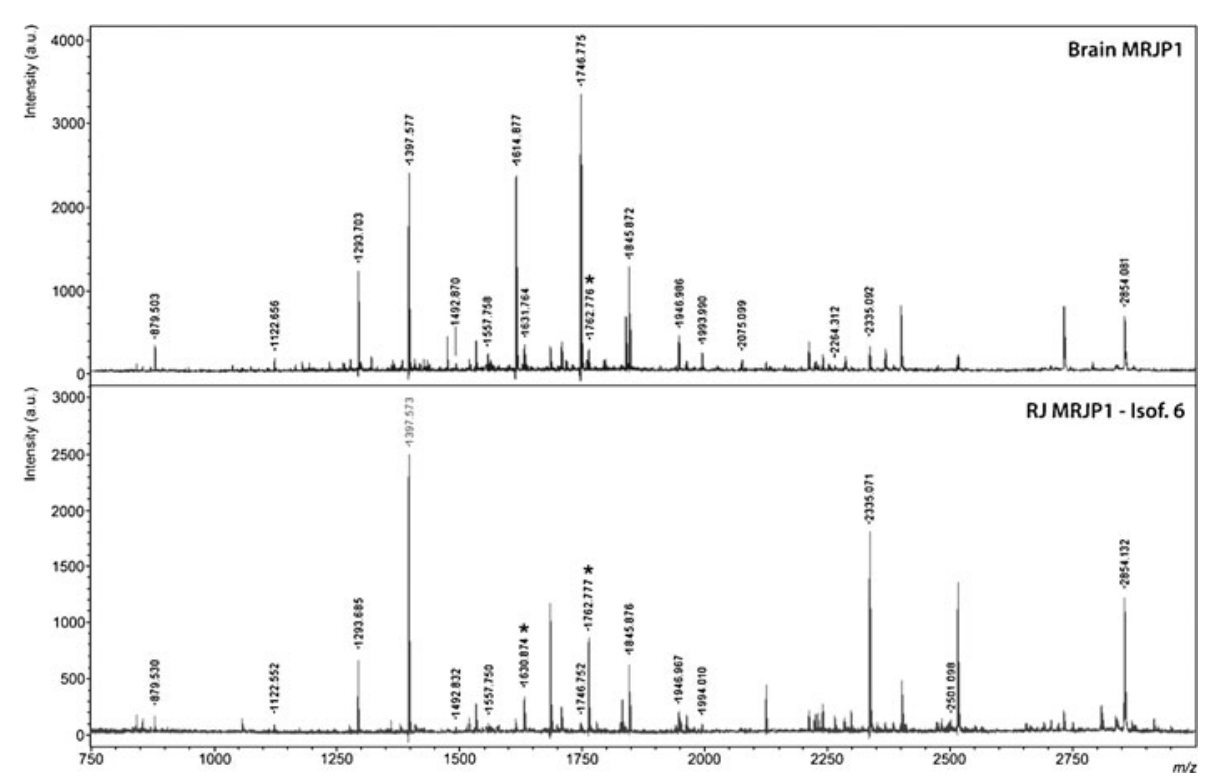

Figure 4. MALDI-TOF mass spectra of tryptic digests from spots of brain and royal jelly MRJP1s. Protein spot isoform 6 in Figure 2 and protein spot indicated by an arrow in Figure 3 were submitted to identification by MALDI-TOF MS analysis. Both proteins were identified as major royal jelly protein 1 from Apis mellifera. Only $\mathrm{m} / \mathrm{z}$ values of peptides matched to database are indicated in the spectra. *Molecular ions matching to peptides containing oxidized methionine.

presenting high numbers of ion peak with identical masses and intensities (data not shown). These data suggest that the MRJP1 purified from royal jelly is the same protein as the one found in bee brain.

\subsection{Conformational state and stability of MRJP1}

The purified MRJP1 presented a polydisperse profile $(25-30 \% P d)$ as evaluated by DLS. The sample showed averaged hydrodynamic diameter $\left(D_{H}\right)$ of $13.4 \mathrm{~nm}$ for $\mathrm{pH}$ 7.0, which allowed inferring a pentameric structure for MRJP1 (with $\sim 290 \mathrm{kDa}$ ) at $1 \mu \mathrm{M}, 3 \mu \mathrm{M}$ (data not shown) and $10 \mu \mathrm{M}$ (Figure 5). However, a hexameric state of MRJP1 was found at $\mathrm{pH} 8.0$ and $\mathrm{pH} 9.0$, with $D_{H}=14.3 \mathrm{~nm}(\sim 340 \mathrm{kDa})$. The main peak at $\mathrm{pH} 6.0$ also evidenced the pentameric formation (Figure 5). As expected, some aggregation (about $2.5 \%$ mass) was observed for $25 \mu \mathrm{M}$ MRJP1 at $\mathrm{pH} 7.0$ (data not shown).
Physicochemical and structural characterization of MRJP1 was carried out by using thermal denaturation, evaluated by Far-UV circular dichroism spectroscopy. Thermal stability of the protein at $\mathrm{pH} 7.0$ was assessed upon raising the temperature from 20 to $95^{\circ} \mathrm{C}$ (Figure 6). The thermostability was assumed considering a curve decline in molar ellipticity along with the increase of temperature. The secondary structure content of MRJP1 at $\mathrm{pH} 7.0$ calculated from the $\mathrm{CD}$ spectrum at $20^{\circ} \mathrm{C}$ was: $9.6 \% \alpha$-helix, $38.3 \%$ antiparallel and parallel $\beta$-sheets and $20 \% \beta$-turn. The $\mathrm{CD}$ spectra in temperature ranging from 20 to $95^{\circ} \mathrm{C}$ show a gradual, slight increase of the dichroic signal (downward), suggesting that the protein gains structure as a function of temperature (Figure 6). A little decrease was observed in terms of $\alpha$-helix content (from $9.6 \%$ to $9.1 \%$ ) and $\beta$-sheet (from $38.3 \%$ to $37.2 \%$ ), and a discrete increase in $\beta$-turn (from $20.0 \%$ to $21.6 \%$ ) and random structures (from $36.0 \%$ to $36.7 \%$ ) (Figure 6, inset). 


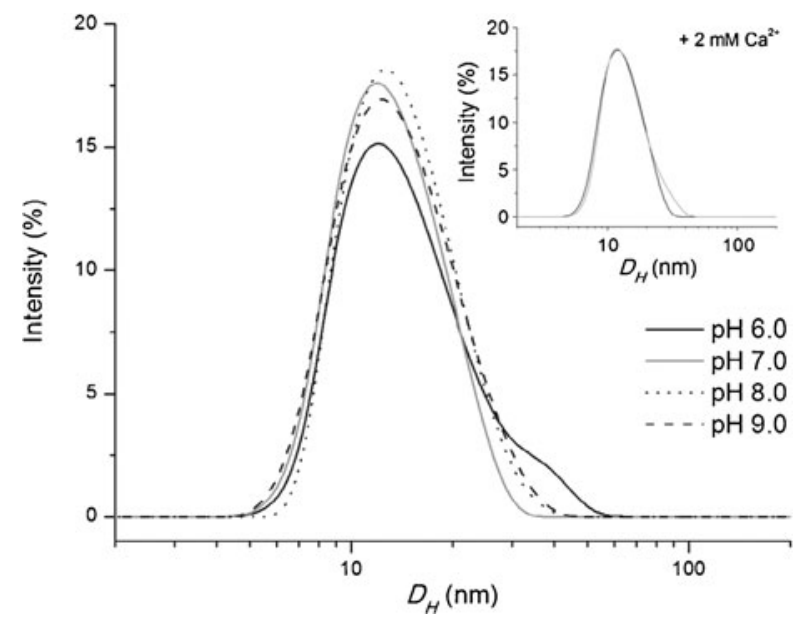

Figure 5. Analysis of the MRJP1 size distribution by DLS. $10 \mu \mathrm{M}$ of MRJP1 was used for all conditions. Protein was diluted in $10 \mathrm{mM}$ sodium acetate $\mathrm{pH}$ 6.0, $10 \mathrm{mM}$ HEPES pH 7.0 or $\mathrm{pH} 8.0,10 \mathrm{mM}$ CHES pH 9.0, as indicated. Inset graphic - Light scattering profile of MRJP1 in absence - and presence - of $2 \mathrm{mM} \mathrm{CaCl}_{2}$ in $10 \mathrm{mM}$ HEPES $\mathrm{pH}$ 7.0.

The thermostability of MRJP1 was also observed either in presence of 200 and $400 \mathrm{mM}$ sodium chloride or $0.5,1.0$ and 1.5 $\mathrm{M}$ guanidine, as evidenced by no significant changes on the molar ellipticity as function of the temperature (data not shown). A reduction in the dichroic signal was observed when adding $400 \mathrm{mM}$ sodium chloride or $1.5 \mathrm{M}$ guanidine at $20^{\circ} \mathrm{C}$, but no indicative of full protein denaturation (data not shown). The denaturation was only achieved when $2 \mathrm{mM}$ calcium chloride was added to the buffer at $\mathrm{pH} 4.0, \mathrm{pH} 5.0$ (data not shown), $\mathrm{pH} 6.0$ (Figure $7 \mathrm{c}$ and $\mathrm{d}$ ) or $\mathrm{pH} 7.0$ (Figure $7 \mathrm{~d}$ ), but not at $\mathrm{pH} 3.0$ (Figure 7a), $\mathrm{pH} 8.0$ (Figure $7 \mathrm{~b}$ ) or pH 9.0 (not shown).

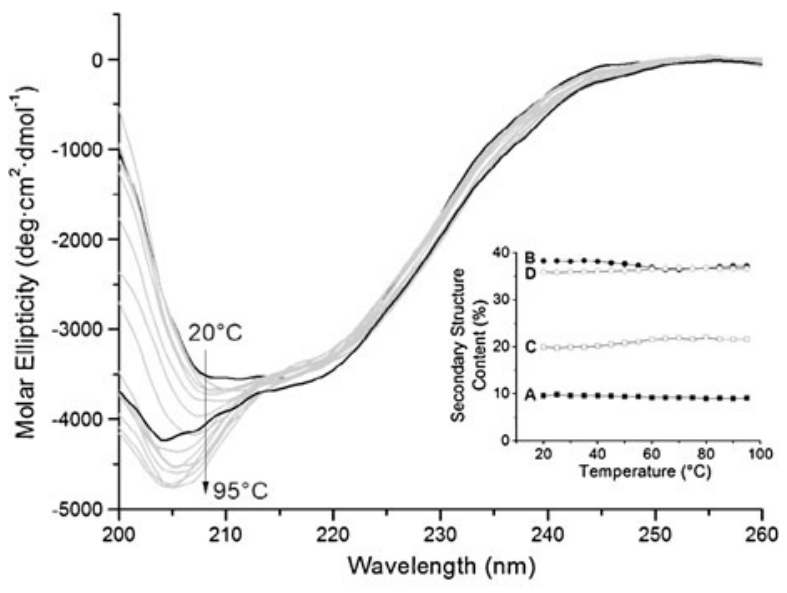

Figure 6. Far-UV CD spectra of MRJP1 as a function of temperature. Protein $(5 \mu \mathrm{M})$ was solubilized in $2 \mathrm{mM}$ HEPES $\mathrm{pH}$ 7.0. The arrow indicates the increase in molar ellipticity as a function of the increase of temperature. The secondary structure contents estimated from these spectra are presented in the inset as follows: a $\alpha$-helix; $\mathbf{b} \beta$-sheet; $\mathbf{c} \beta$-turn; and $\mathbf{d}$ other content as a function of the temperature. 
DLS analyses showed that MRJP1 appears as an aggregate at $\mathrm{pH} 4.0$ or $\mathrm{pH} 5.0$, in spite of showing typical denaturation curves in $\mathrm{CD}$ analyses, when in the presence of $2 \mathrm{mM} \mathrm{CaCl}_{2}$ (data not shown). Thus, no thermodynamic parameters characterizing the structural stability of the protein could be calculated for these conditions.

Protein stability is defined by measurements of thermodynamic parameters, and the reversibility of the unfolding reaction is essential for such experiments (Pace et al. 1997). Indeed, the degree of irreversibility for a protein increases as a function of its exposition time to unfolding conditions. In the case of MRJP1, the thermal unfolding took approximately $3 \mathrm{~h}$, a drastic condition that promoted the protein aggregation and turned the thermal unfolding reaction irreversible (data not shown). In spite of that, we estimated the thermodynamic parameters from the normalized $\mathrm{CD}$ data at $\mathrm{pH} 6.0$ and 7.0. However, such thermodynamic parameters do not correspond to the real stability of MRJP1, once its thermal unfolding was an irreversible process. The melting temperature of unfolding $(\mathrm{Tm})$ was higher at $\mathrm{pH} 6.0\left(87.34^{\circ} \mathrm{C}\right)$ than at $\mathrm{pH} 7.0\left(82.80^{\circ} \mathrm{C}\right)$. The Gibbs free energy $\left(\Delta G^{25}\right)$ calculated for $\mathrm{pH} 6.0$ and 7.0 were $68.262 \mathrm{~kJ} \mathrm{~mol}^{-1}$ and $62.943 \mathrm{~kJ} \mathrm{~mol}^{-1}$, respectively, which suggests a high stability for MRJP1 in these conditions. This can also be depicted by the higher value of enthalpy change ( $\Delta H m$ above $387 \mathrm{~kJ} \mathrm{~mol}^{-1}$ ) estimated for these two conditions. The entropy change $(\Delta S m)$ was low for the tested conditions, indicating the predominant contribution of enthalpy change to the $\Delta G^{25}$ of the protein. In general, the much higher value of $\Delta H m$ reflects a higher $\Delta G^{25}$ given by the Gibbs-Helmholtz relationship or likewise by Eq. 4 (see Section 2).

The CD spectra of MRJP1 in the presence of $2 \mathrm{mM}$ calcium chloride were very similar for $\mathrm{pH}$ 4.0, pH 5.0, $\mathrm{pH} 6.0$ and $\mathrm{pH} 7.0$ at $25^{\circ} \mathrm{C}$ (data not shown). Moreover, $2 \mathrm{mM} \mathrm{CaCl}_{2}$ did not cause significant change in the molecule as indicated by DLS profile at $\mathrm{pH} 7.0$ and $25^{\circ} \mathrm{C}$ (Figure 5, inset), suggesting that calcium itself does not promote considerable structure alteration in MRJP1 at room temperature.

\section{DISCUSSION}

Major Royal Jelly Protein 1 (MRJP1) is an acidic protein and the most abundant component of royal jelly, representing $48 \%$ of total water soluble protein (Simuth et al. 2004; Scarselli et al. 2005). Due to abundance in royal jelly, the purification was performed from that material. A single purification step using anion exchange FPLC chromatography was required to purify MRJPs. Two of the main fractions presented single bands in silver staining under SDS-PAGE (Figure 1, inset) indicating the co-isolation of two polypeptides with different masses by our new single step purification procedure, MRJP1 and MRJP2 (Table I). Ordinary isolation methods of MRJPs led to protein precipitates and aggregates designated as water-insoluble proteins (Chen and Chen 1995) and previous MRJP1 purification methods were multi-step and time consuming (Kamakura et al. 2001a; Simuth 2001). An earlier attempt to purify and characterize MRJPs was carried out by low resolution chromatographic and electrophoretic methods, which led to obtaining a mixture of MRJPs (Hanes and Simuth 1992). The MRJP1 purification herein was confirmed by SDS-PAGE, 2DE and MS analyses (Figure 1, inset; 2 and 4). As MRJP1 is the principal royal jelly protein, we focused on its characterization in this work, whereas MRJP2 will be treated elsewhere after further characterization.

Hanes and Simuth (1992) had found eight isoforms from $\mathrm{p} I 4.5$ to 5.0 for the major royal jelly protein (which was further classified as MRJP1 later) by isoelectric focusing. In this work, we could observe nine different isoforms of MRJP1 by 2-DE (Figure 2; Table II). This multiplicity of isoforms is probably due to posttranslational modifications (PTMs) in the protein, as different degrees of protein glycosylation (Ohashi et al. 1997) or maybe to the genetic variability among the bees in the hive (Schmitzova et al. 1998). Phosphorylation is 

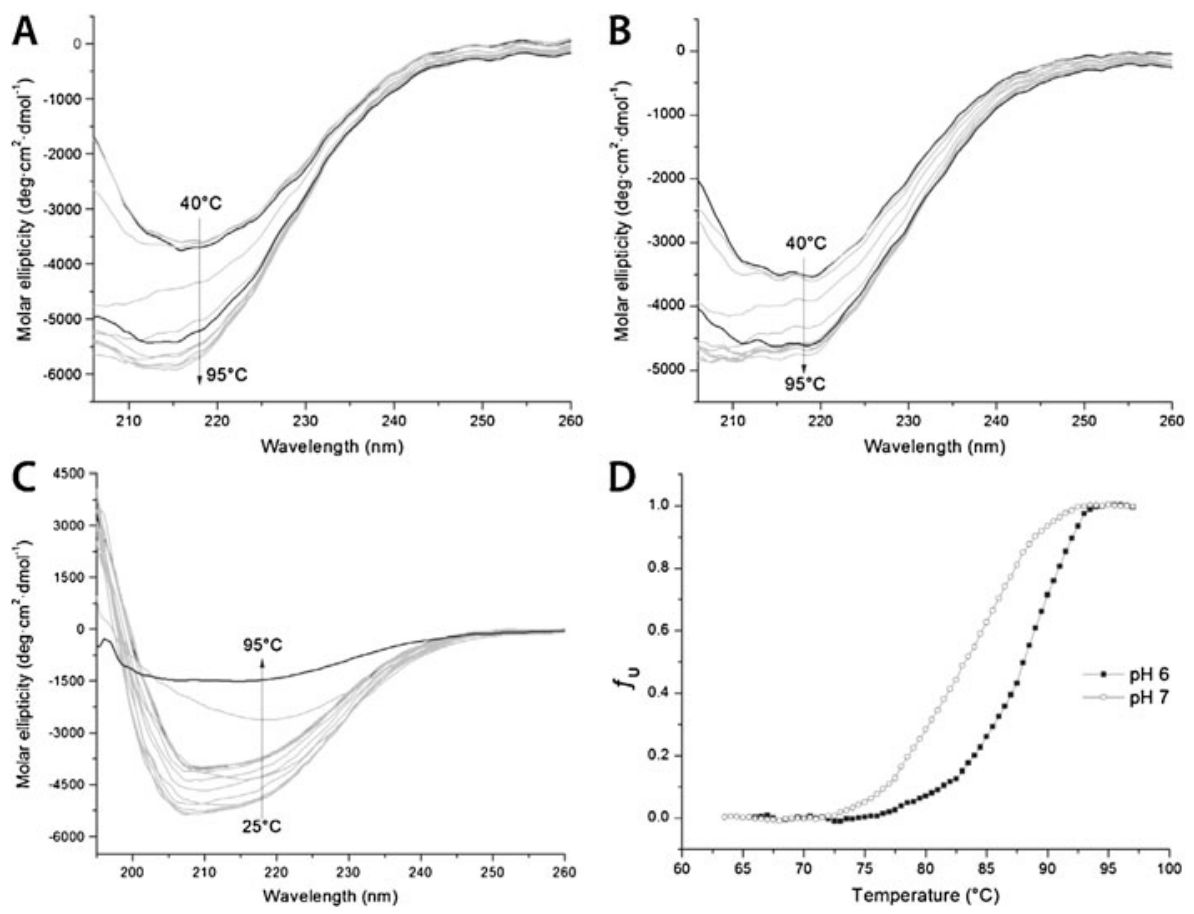

Figure 7. Fitted heat-induced unfolding curves of MRJP1. a CD spectra of MRJP1 in $2 \mathrm{mM}$ sodium citrate pH 3.0 containing $2 \mathrm{mM} \mathrm{CaCl}_{2}$. b CD spectra of MRJP1 in $2 \mathrm{mM}$ HEPES pH 8.0 containing $2 \mathrm{mM} \mathrm{CaCl}_{2}$. c CD spectra of MRJP1 in $2 \mathrm{mM}$ sodium acetate $\mathrm{pH} 6.0$ containing $2 \mathrm{mM} \mathrm{CaCl}_{2}$. d Normalized data for the denaturing conditions $(\mathrm{pH} 6.0$ and 7.0 with $2 \mathrm{mM} \mathrm{CaCl} 2)$; fraction of unfolded protein $\left(f_{U}\right)$ as a function of temperature. The arrows indicate the decrease (downward) or increase (upward) of the molar ellipticity as the temperature increases.

disregarded as 2-DE analysis showed that MRJP1 isoforms are glycoproteins, but not phosphoproteins (Furusawa et al. 2008).

Despite the existence of a single gene coding for MRJP1 in the honey bee genome (Consortium 2006; Drapeau et al. 2006), the expressed gene products can only be assessed at the proteomic level. Alternative splicing of a gene transcript may result in distinct protein species. PTMs can also provide protein diversity. Additionally, the mRNA abundance is not always correlated to protein levels (Gygi et al. 1999; Chen et al. 2002).

In a previous work, we showed the presence of MRJP1 in the honey bee brain both by 2-DE of the brain proteome and by immunocytochemistry of brain tissue (Garcia et al. 2009). Comparing the MRJP1s purified from royal jelly and brain tissue by 2-DE (Figures 2 and 3) and MS of tryptic digests (Figure 4), a great similarity was observed considering the mass peaks of MRJP1 peptides from both sources. Two of the peptides presenting methionine oxidation, $m / z 1630.8$ and 1762.7, appeared more intense in the spectrum of royal jelly MRJP1, whereas the unmodified components ( $\mathrm{m} / \mathrm{z} 1614.8$ and 1746.7) showed to be more intense in the brain sample. Those ions were then selected and actually confirmed by fragmentation and MS/MS sequencing as MRJP1 peptides, both oxidized and non-modified. Methionine oxidation is a spontaneous process occurring in proteins when exposed to reactive oxygen species (Vogt 1995). Once the cerebral MRJP1 is found in the brain cells (Garcia et al. 2009; Peixoto et al. 2009), it would be less 
susceptible to oxidation reactions than royal jelly MRJP1. Royal jelly presents a certain antioxidative activity (Nagai et al. 2001, 2006), and its collection and storage often occurs carefully (Kamakura et al. 2001a; Furusawa et al. 2008) because of its commercial use. However, its constituent proteins are exposed for longer to the air than those enclosed in a tissue, so that they may undergo greater oxidative modifications.

Two low intense peaks $(\mathrm{m} / \mathrm{z} 2075.1$ and 2264.3) were found only in the brain MRJP1 spot and another one $(\mathrm{m} / \mathrm{z} 2501.1)$ was verified only in the spectrum of the secreted protein. However, these peaks are probably derived from processes normally occurring during the experiments, like missed cleavages at lysines or alkylation of cysteines. Altogether, data from relative mobility of protein in gels (SDS-PAGE and 2-DE), protein identification by PMF and comparison of the tryptic digests by MS, lead us to propose that the MRJP1 purified from royal jelly is the same glycoprotein present in honey bee brain.

DLS demonstrated the structural selfassembling of MRJP1 in solution, in agreement with previous reports (Kimura et al. 1995, 1996, 2003; Tamura et al. 2009a, b). The predominance of pentamers $(\sim 290 \mathrm{kDa})$ was evidenced at $\mathrm{pH} 6.0$ and $\mathrm{pH} 7.0$ (Figure 5), which are in agreement with recent works of Tamura et al. (2009a, b). However, herein we also show that MRJP1 predominantly forms hexamers $(\sim 340 \mathrm{kDa})$ at $\mathrm{pH} 8.0$ and $\mathrm{pH} 9.0$ (Figure 5), indicating a pH-dependence on the MRJP1 oligomerization process.

Actually, a $350 \mathrm{kDa}$ bioactive glycoprotein (later named apisin) was isolated from royal jelly (Yonekura et al. 1992; Kimura et al. 1995) as a heterocomplex composed by two distinct subunits (Kimura et al. 1996). One of them showed the N-terminal sequence Asn-Ile-LeuArg-Gly identical to that of MRJP1, while the other one presented the N-terminal sequence of apisimin (Lys-Thr-Ser-Ile-Ser), a peptide characterized 6 year later (Bilikova et al. 2002). A tryptic peptide from apisin showed an identical sequence to the region Gln167-Lys182 of
MRJP1 (Kimura et al. 2003). Recently, it was revealed that MRJP1 forms an heterooligomeric complex with apisimin, which was suggested to serve as a subunit-joining protein within the MRJP1 oligomer (Tamura et al. 2009a).

About $2.5 \%$ of MRJP1 appeared as aggregate at concentrations as high as $25 \mu \mathrm{M}$ in $\mathrm{pH} 7.0$ (data not shown). It is well known that high concentrations of protein may lead to selfassociation of the native state. To date, there is little available information about the physicochemical or structural characterization of MRJP1. In this work we analyzed some structural features of this protein, important for the nourishment of honey bee larvae and probably possessing an unknown function into the neural tissue of the insect. CD analyses showed the secondary structure content of MRJP1 predominantly formed by $\beta$-sheets (38.3\% parallel and antiparallel). Protein stability can be indirectly evaluated by the Gibbs energy change estimated from the transition curves of native to the unfolded state (Pace 1990; Pace et al. 1997; Teles et al. 2005). The thermal denaturation curves analyzed from FarUV CD measurements strongly indicated the MRJP1 as a thermally stable protein (Figure 6). The conformational changes could be verified by analyzing its secondary structure content throughout the temperature range of 20 to $95^{\circ} \mathrm{C}$ (Figure 6, inset), even so this was not considered a denaturation process. However, in order to estimate the structural stability of the MRJP1, we searched for conditions in which the denaturation process could occur. Changing the ionic strength of the solution with sodium chloride or disturbing the protein environment with a low concentration of guanidine hydrochloride, significant structural changes were not observed as indicated by low variations on the Far-UV CD spectra (data not shown). In a recent work, we had identified MRJP1 as a calmodulin-binding protein (CaMBP) (Calabria et al. 2008). Calmodulin interacts with target proteins under regulation of calcium (Rhoads and Friedberg 1997). Considering this feature we analyzed the effect of the calcium ion on 
MRJP1 structural stability. The MRJP1 denaturation process was followed after the addition of $2 \mathrm{mM} \mathrm{CaCl}_{2}$ to the protein solution at $\mathrm{pH} 4.0, \mathrm{pH} 5.0$ (data not shown), $\mathrm{pH} 6.0$ (Figure $7 \mathrm{c}$ and $\mathrm{d}$ ) and $\mathrm{pH} 7.0$ (Figure $7 \mathrm{~d}$ ). The thermodynamic parameters obtained at $\mathrm{pH} 6.0$ and $\mathrm{pH} 7.0$ indicate a remarkable stability of MRJP1 in which $T m$ occurs at temperatures above $82.8^{\circ} \mathrm{C}$, in agreement with most mesophilic and thermophilic globular proteins (Kumar et al. 2000, 2001), human lysozyme, parvalbumin, RNase T1, thioredoxin and whale myoglobin (Robertson and Murphy 1997).

The high stability of MRJP1 was also verified by the enthalpy change $\left(>387 \mathrm{~kJ} \mathrm{~mol}^{-1}\right)$ and the Gibbs free energy $\left(>62 \mathrm{~kJ} \mathrm{~mol}^{-1}\right)$, indicating that MRJP1 is well packed by many non-covalent interactions. The $\Delta G^{25}$ is very high and quite dependent on the $\Delta H m$ values. The value attributed to the entropy is associated with the increase of conformational freedom in the polypeptide chain and with the hydration of groups that become exposed on unfolded state.

DLS analyses also revealed the tendency of MRJP1 to aggregate at $\mathrm{pH} 4.0$ and $\mathrm{pH} 5.0$ (close to its $\mathrm{p} I$ values between 4.7 and 5.2), in spite of a transition curve obtained from an unfolding process in presence of calcium as seen in CD experiments. However, unfolding assays devoided of aggregation should be developed in order to gather further concluding data about the high stability of MRJP1 in pHs close to $\mathrm{p} I$ values.

Analyses of CD spectra of MRJP1 reveal a $\mathrm{pH}$-dependence of its thermal denaturation with the maximum stability $\left(\sim 68 \mathrm{~kJ} \mathrm{~mol}^{-1}\right)$ coinciding with $\mathrm{pH}$ 6.0. CD spectra of MRJP1 at $\mathrm{pH}$ 4.0-7.0 revealed a typical two-state transition from native to unfolded states (see Figure 7c and d for $\mathrm{pH} 6.0$ and 7.0). However, the thermal unfolding of MRJP1 was an irreversible process, as indicated by $\mathrm{CD}$ rescanning under protein sample cooling $\left(40^{\circ} \mathrm{C}\right)$ after its complete thermal unfolding $\left(95^{\circ} \mathrm{C}\right.$ ) (data not shown). Thermodynamic measurements require the unfolding reaction to reach the equilibrium and to be reversible (Pace et al. 1997). Hence, present $\mathrm{CD}$ data collection was performed taking into account a slow increase in temperature $\left(0.5^{\circ} \mathrm{C} / \mathrm{min}\right)$, allowing the equilibrium to be achieved. On the other hand, it is known that protein solubility drastically decreases at high temperatures, resulting in aggregation due to hydrophobic amino acid residues exposure. The longer a protein is submitted to high temperature conditions, greater its aggregation is, preventing the refolding process. As considered by Pace et al. (1997), reversibility of thermal unfolding barely occurs due to the above mentioned effect. Therefore, thermodynamic parameter estimated herein could not correspond the real values of MRJP1 stability.

The electrostatic interactions, the chemical basis and the mechanistic origin that would explain the pH-dependence on MRJP1 selfassociation and stability could be elucidated from the three-dimensional structure of the protein, which has not been solved so far.

No pattern of protein denaturation could be verified on the CD spectra at $\mathrm{pH} 3.0$ (Figure 7a), $\mathrm{pH} 8.0$ (Figure $7 \mathrm{~b}$ ) or $\mathrm{pH} 9.0$ (not shown) conditions, even in the presence of calcium ions. Calcium form ionic interactions with the side chains of aspartate and glutamate residues (Marsden et al. 1990; Handford et al. 1991), which can modify interactions in the protein, and consequently, its conformational stability. These residues are largely protonated at $\mathrm{pH} 3.0$ and the protein interactions with calcium would be hampered, keeping the protein conformation closest to the native state. In alkaline conditions, as well as $\mathrm{pH} 3.0$, it was verified a gain in structure by MRJP1 when raising the temperature (Figure $7 \mathrm{a}$ and $\mathrm{b}$ ). This fact was also observed for other $\mathrm{pH}$ conditions before the occurrence of denaturation process. Possibly the protein unfolding at extreme $\mathrm{pHs}$ would take place at higher temperatures not assessed by the present techniques.

In conclusion, the purification of both MRJP1 and MRJP2 was concomitantly achieved through a simple, fast and single step method. Purified MRJP1 was obtained in oligomeric states, and showed to be a thermally stable protein. Upon heating, calcium ions 
probably caused conformational changes on MRJP1 that make it susceptible to temperature and $\mathrm{pH}$ effects. The present work represents an effort on the structural characterization of MRJP1. The MRJP1 gene transcription (Kucharski et al. 1998) and expression in the honey bee brain (Garcia et al. 2009; Peixoto et al. 2009) reinforce the hypothesis of a protein possessing novel functions besides the nutritional role. The physicochemical and structural data of MRJP1 will certainly lead to better comprehension of its functions in honey bee neural processes in the future.

\section{ACKNOWLEDGEMENTS}

The authors thank the collaboration of Dr. Fabio A. Schaberle (LNLS) for the help on conducting DLS and $\mathrm{CD}$ experiments, Manoel Silva for the supply of honey bees and Nuno M. Domingues for technical assistance in FPLC.

This work was supported by grants from Research and Projects Financing (FINEP, Brazil) to the Brazilian Center for Protein Research, University of Brasilia, and from the Brazilian Council for Scientific and Technological Development (CNPq) to M.V.S. [477258/2007-7], C.A.O.R. [474609/2008-1] and S. M.F. [305022/2009-1]. A grant from the Brazilian Association of Synchrotron Light Technology (ABTLuS) supports LNLS facilities. Fellowship to G.C.N. $\mathrm{C}$ was awarded by Coordination for the Improvement of Higher Level Personnel (CAPES) and to L.G.H. by The Academy of Sciences for the Developing World (TWAS).

Effet du calcium et dépendance au pH sur l'autoassociation et la stabilité structurelle de la protéine majeure 1 de la gelée royale d'Apis mellifera.

MRJP1 / Apis mellifera / stabilité de la protéine / spectrométrie de masse / dichroïsme circulaire

Zusammenfassung - Bedeutung des Kalzium Effekts und der pH-Abhängigkeit für die Selbstassoziation und Strukturstabilität des Apis mellifera Gelée royale Proteins 1 (major royal jelly protein 1). Die Hauptproteine in Gelée royale (Major royal jelly proteins, MRJPs) der Honigbiene sind eine Nahrungsquelle für Larven und von Bedeutung für deren Differenzierung in Königinnen. MRJPs weisen Sequenzähnlichkeit mit den Yellow Proteinen von Drosophila melanogaster und anderen Insekten, sowie mit bakteriellen Proteinen auf. Über die biologische Funktion von MRJPs ist wenig bekannt, einige Untersuchungen deuten aber auf eine Rolle in der geschlechtsspezifischen reproduktiven Reifung und in Entwicklungsprozessen des Nervensystems hin. MRJP1 ist das Hauptprotein in Gelée royale. Es ist ein 55-57 kDa Glykoprotein, das im Drüsensekt in monomerer oder oligomerer Form vertreten sein kann. Im Gehirn kommt MRJP1 in Interzellularräumen und in Verbindung mit dem Zytoskelett vor und ist dort während der Entwicklung und während des

Übergangs von der Stockbiene zur Sammlerin differentiell exprimiert. MRJP1 könnte demzufolge in verschiedenen biologischen Vorgängen eine Rolle spielen, wenngleich seine Bedeutung im Nervengewebe noch unklar ist und nur wenige Strukturinformationen über dieses Protein vorliegen. MRJP1 wurde aus Gelée royale mittels einer neuen, schnellen Einschrittmethode chromatographisch aufgereinigt (Abb. 1, Table I). Neun verschiedene MRJP1 Isoformen konnten mittels zweidimensionaler Elektrophorese aufgetrennt werden (Abb. 2, Table II). Durch die Kopplung einer zweidimensionalen Elektrophorese mit Massenspektrometrieanalyse konnten wir proteomisch zeigen, dass MRJP1 des Nervengewebes mit dem entsprechenden Protein aus Gelée royale identisch ist (Abb. 3 und 4). Mittels Dynamischer Lichtverteilung (Dynamic Light Scattering, DLS) wurden die oligomeren Formen von MRJP1 ermittelt. Eine pentamere Form war bei $\mathrm{pH}-$ Werten von 6,0 und $7,0 \mathrm{zu}$ finden, während eine hexamere bei $\mathrm{pH}-$ Werten von 8,0 und 9,0 auftrat (Abb. 5). Anhand von Zirkulärdichroismus(CD)-Spektren konnten wir zeigen, dass MRJP1 ein sehr stabiles Protein ist (Abb. $6)$. Eine $\beta$-Faltenstruktur war mit $38,3 \%$ die überwiegende Proteinstruktur in MRJP1 (Einsatz in Abb. 6). Entfaltungskurven, die mittels CD-Spektrenanalyse bei unterschiedlichen Temperaturen aufgenommen wurden, deuten ebenfalls auf hohe Stabilität bei unterschiedlichen $\mathrm{pH}$-Werten hin. Die Zugabe von Kalziumionen führte jedoch zu Konformationsänderungen, die MRJP1 für Temperatur- und pH-Effekte anfällig mach-ten (Abb. 7). In der Gegenwart von $2 \mathrm{mM}$ Kalzium lag die maximale Stabilität bei $\mathrm{pH}$ 6,0 , mit einem $\mathrm{Tm}$-Wert über $87^{\circ} \mathrm{C}, \Delta H m$ über $394 \mathrm{~kJ} \mathrm{~mol}^{-1}$ und $\Delta G^{25}$ über $68 \mathrm{~kJ} \mathrm{~mol}^{-1}$. Hohe Tm-Werte von über $82^{\circ} \mathrm{C}, \Delta H_{m}$ über $387 \mathrm{~kJ}$ mol-1 und $\Delta G^{25}$ über $62 \mathrm{~kJ}$ mol-1 wurden auch bei $\mathrm{pH} 7,0$ gefunden. Der Nach-weis der Expression des 
MRJP1-Gens im Gehirn der Honigbiene deutet darauf hin, das dieses Protein eine Rolle spielen könnte, die über die der Nah-rungsfunktion hinausgeht. Die Ergebnisse dieser Studie stellen einen Ansatz zur Struktur-Funktions- Charakterisierung von MRJP1 dar, und derartige physikochemische Daten können zu einem besseren Verständnis der Funktionen dieses Proteins bei-tragen.

\section{MRJP1 / Apis mellifera / Proteinstabilität / Mas- senspektrometrie / Zirkulärdichroismus}

Open Access This article is distributed under the terms of the Creative Commons Attribution Noncommercial License which permits any noncommercial use, distribution, and reproduction in any medium, provided the original author(s) and source are credited.

\section{REFERENCES}

Albert, S., Klaudiny, J. (2004) The MRJP/YELLOW protein family of Apis mellifera: identification of new members in the EST library. J. Insect Physiol. 50, 51-59

Albert, S., Bhattacharya, D., Klaudiny, J., Schmitzova, J., Simuth, J (1999) The family of major royal jelly proteins and its evolution. J. Mol. Evol. 49, 290-297

Bilikova, K., Hanes, J., Nordhoff, E., Saenger, W., Klaudiny, J., Simuth, J. (2002) Apisimin, a new serine-valine-rich peptide from honeybee (Apis mellifera L.) royal jelly: purification and molecular characterization. FEBS Lett. 528, 125-129

Blum, H., Beier, H., Gross, H.J. (1987) Improved silver staining of plant proteins. RNA and DNA in polyacrylamide gels. Electrophoresis 8, 93-99

Böhm, G. (1997) CDNN-CD Spectra Deconvolution, Halle

Bradford, M.M. (1976) A rapid and sensitive method for the quantitation of microgram quantities of protein utilizing the principle of protein-dye binding. Anal. Biochem. 72, 248-254

Calabria, L.K., Garcia, L., Teixeira, R.R., Sousa, M.V., Espindola, F.S. (2008) Identification of calmodulinbinding proteins in brain of worker honeybees. Comp. Biochem. Physiol. B. Biochem. Mol. Biol. 151, 41-45

Chen, C., Chen, S.-Y. (1995) Changes in protein components and storage stability of Royal Jelly under various conditions. Food Chem. 54, 195-200

Chen, G., Gharib, T.G., Huang, C.C., Taylor, J.M., Misek, D.E., Kardia, S.L., Giordano, T.J., Iannettoni, M.D., Orringer, M.B., Hanash, S.M., Beer, D.G. (2002) Discordant protein and mRNA expression in lung adenocarcinomas. Mol. Cell Proteomics 1, 304-313
Consortium, T.H.G.S. (2006) Insights into social insects from the genome of the honeybee Apis mellifera. Nature 443, 931-949

Drapeau, M.D., Albert, S., Kucharski, R., Prusko, C., Maleszka, R. (2006) Evolution of the Yellow/Major Royal Jelly Protein family and the emergence of social behavior in honey bees. Genome Res. 16, 1385-1394

Evans, J.D., Wheeler, D.E. (2001) Gene expression and the evolution of insect polyphenisms. Bioessays 23, 62-68

Fahrbach, S.E., Robinson, G.E. (1995) Behavioral development in the honey bee: toward the study of learning under natural conditions. Learn. Mem. 2, 199-224

Frisken, B.J. (2001) Revisiting the method of cumulants for the analysis of dynamic light-scattering data. Appl. Opt. 40, 4087-4091

Furusawa, T., Rakwal, R., Nam, H.W., Shibato, J., Agrawal, G.K., Kim, Y.S., Ogawa, Y., Yoshida, Y., Kouzuma, Y., Masuo, Y., Yonekura, M. (2008) Comprehensive royal jelly (RJ) proteomics using one- and two-dimensional proteomics platforms reveals novel RJ proteins and potential phospho/ glycoproteins. J. Proteome Res. 7, 3194-3229

Futahashi, R., Sato, J., Meng, Y., Okamoto, S., Daimon, T., Yamamoto, K., Suetsugu, Y., Narukawa, J., Takahashi, H., Banno, Y., Katsuma, S., Shimada, T., Mita, K., Fujiwara, H. (2008) Yellow and ebony are the responsible genes for the larval color mutants of the silkworm Bombyx mori. Genetics 180, 19952005

Garcia, L., Garcia, C.H.S., Calabria, L.K., Cruz, G.C.N., Puentes, A.S., Bao, S.N., Fontes, W., Ricart, C.A., Espindola, F.S., Sousa, M.V. (2009) Proteomic analysis of honey bee brain upon ontogenetic and behavioral development. J. Proteome Res. 8, 1464-1473

Gharahdaghi, F., Weinberg, C.R., Meagher, D.A., Imai, B. S., Mische, S.M. (1999) Mass spectrometric identification of proteins from silver-stained polyacrylamide gel: a method for the removal of silver ions to enhance sensitivity. Electrophoresis 20, 601-605

Gygi, S.P., Rochon, Y., Franza, B.R., Aebersold, R. (1999) Correlation between protein and mRNA abundance in yeast. Mol. Cell. Biol. 19, 1720-1730

Handford, P.A., Mayhew, M., Baron, M., Winship, P.R., Campbell, I.D., Brownlee, G.G. (1991) Key residues involved in calcium-binding motifs in EGF-like domains. Nature 351, 164-167

Hanes, J., Simuth, J. (1992) Identification and partial characterization of the major royal jelly protein of the honey bee (Apis mellifera L.). J. Apic. Res. 31, 22-26

Hassan, P.A., Kulshreshtha, S.K. (2006) Modification to the cumulant analysis of polydispersity in quasielastic light scattering data. J. Colloid Interface Sci. 300, 744-748

Kamakura, M., Fukuda, T., Fukushima, M., Yonekura, M. (2001a) Storage-dependent degradation of 57$\mathrm{kDa}$ protein in royal jelly: a possible marker for 
freshness. Biosci. Biotechnol. Biochem. 65, 277284

Kamakura, M., Mitani, N., Fukuda, T., Fukushima, M. (2001b) Antifatigue effect of fresh royal jelly in mice. J. Nutr. Sci. Vitaminol. 47, 394-401

Kamakura, M., Suenobu, N., Fukushima, M. (2001c) Fifty-seven-kDa protein in royal jelly enhances proliferation of primary cultured rat hepatocytes and increases albumin production in the absence of serum. Biochem. Biophys. Res. Commun. 282, $865-874$

Kimura, Y., Washino, N., Yonekura, M. (1995) N-linked sugar chains of $350-\mathrm{kDa}$ royal jelly glycoprotein. Biosci. Biotechnol. Biochem. 59, 507-509

Kimura, Y., Kajiyama, S., Kanaeda, J., Izukawa, T., Yonekura M. (1996) N-linked sugar chain of 55-kDa royal jelly glycoprotein. Biosci. Biotechnol. Biochem. 60, 2099-2102

Kimura, M., Kimura, Y., Tsumura, K., Okihara, K., Sugimoto, H., Yamada, H., Yonekura, M. (2003) $350-\mathrm{kDa}$ royal jelly glycoprotein (apisin), which stimulates proliferation of human monocytes, bears the beta1-3galactosylated N-glycan: analysis of the Nglycosylation site. Biosci. Biotechnol. Biochem. 67, 2055-2058

Kucharski, R., Maleszka, R., Hayward, D.C., Ball, E.E. (1998) A royal jelly protein is expressed in a subset of Kenyon cells in the mushroom bodies of the honey bee brain. Naturwissenschaften 85, 343-346

Kumar, S., Tsai, C.J., Nussinov, R. (2000) Factors enhancing protein thermostability. Protein Eng. 13, 179-191

Kumar, S., Tsai, C.J., Nussinov, R. (2001) Thermodynamic differences among homologous thermophilic and mesophilic proteins. Biochemistry (Mosc) 40, 14152-14165

Majtan, J., Kovacova, E., Bilikova, K., Simuth, J. (2006) The immunostimulatory effect of the recombinant apalbumin 1 -major honeybee royal jelly proteinon $\mathrm{TNF} \alpha$ release. Int. Immunopharmacol 6, 269-278

Malecova, B., Ramser, J., O’Brien, J.K., Janitz, M., Judova, J., Lehrach, H., Simuth, J. (2003) Honeybee (Apis mellifera L.) mrjp gene family: computational analysis of putative promoters and genomic structure of mrjpl, the gene coding for the most abundant protein of larval food. Gene 303, 165-175

Marsden, B.J., Shaw, G.S., Sykes, B.D. (1990) Calcium binding proteins. Elucidating the contributions to calcium affinity from an analysis of species variants and peptide fragments. Biochem. Cell Biol. 68, 587-601

Menzel, R., Leboulle, G., Eisenhardt, D. (2006) Small brains, bright minds. Cell 124, 237-239

Nagai, T., Sakai, M., Inoue, R., Inoue, H., Suzuki, N. (2001) Antioxidative activities of some commercially honeys, royal jelly, and propolis. Food Chem. 75, 237240

Nagai, T., Inoue, R., Suzuki, N., Nagashima, T. (2006) Antioxidant properties of enzymatic hydrolysates from royal jelly. J. Med. Food 9, 363-367
Ohashi, K., Natori, S., Kubo, T. (1997) Change in the mode of gene expression of the hypopharyngeal gland cells with an age-dependent role change of the worker honeybee Apis mellifera L. Eur. J. Biochem. 249, 797-802

Pace, C.N. (1990) Conformational stability of globular proteins. Trends Biochem. Sci. 15, 14-17

Pace, C.N., Shirley, B.A., Thomson, J.A. (1997) Measuring the conformational stability of a protein. In: Hames BD (ed) Protein structure: a practical approach. Oxford University Press, New York, pp. 299-321

Page, R.E.J., Peng, C.Y. (2001) Aging and development in social insects with emphasis on the honey bee, Apis mellifera L. Exp. Gerontol. 36, 695-711

Peixoto, L.G., Calabria, L.K., Garcia, L., Capparelli, F.E., Goulart, L.R., de Sousa, M.V., Espindola, F.S. (2009) Identification of major royal jelly proteins in the brain of the honeybee Apis mellifera. J. Insect Physiol. 55, 671-677

Perkins, D.N., Pappin, D.J., Creasy, D.M., Cottrell, J.S. (1999) Probability-based protein identification by searching sequence databases using mass spectrometry data. Electrophoresis 20, 3551-3567

Rhoads, A.R., Friedberg, F. (1997) Sequence motifs for calmodulin recognition. FASEB J. 11, 331-340

Robertson, A.D., Murphy, K.P. (1997) Protein Structure and the Energetics of Protein Stability. Chem. Rev. 97, 1251-1268

Scarselli, R., Donadio, E., Giuffrida, M.G., Fortunato, D., Conti, A., Balestreri, E., Felicioli, R., Pinzauti, M., Sabatini, A.G., Felicioli, A. (2005) Towards royal jelly proteome. Proteomics 5, 769-776

Schmitzova, J., Klaudiny, J., Albert, S., Schroder, W., Schreckengost, W., Hanes, J., Judova, J., Simuth, J. (1998) A family of major royal jelly proteins of the honeybee Apis mellifera L. Cell Mol. Life Sci. 54, $1020-1030$

Simuth, J. (2001) Some properties of the main protein of honeybee (Apis mellifera) royal jelly. Apidologie 32, 69-80

Simuth, J., Bilikova, K., Kovacova, E., Kuzmova, Z., Schroder, W. (2004) Immunochemical approach to detection of adulteration in honey: physiologically active royal jelly protein stimulating TNF- $\alpha$ release is a regular component of honey. J. Agric. Food Chem. 52, 2154-2158

Tamura, S., Amano, S., Kono, T., Kondoh, J., Yamaguchi, K., Kobayashi, S., Ayabe, T., Moriyama, T. (2009a) Molecular characteristics and physiological functions of major royal jelly protein 1 oligomer. Proteomics $\mathbf{9}$, 5534-5543

Tamura, S., Kono, T., Harada, C., Yamaguchi, K., Moriyama, T. (2009b) Estimation and characterisation of major royal jelly proteins obtained from the honeybee Apis merifera. Food Chem. 114, 1491-1497

Teles, R.C., Calderon, L.A., Medrano, F.J., Barbosa, J.A., Guimaraes, B.G., Santoro, M.M., de Freitas, S.M. (2005) $\mathrm{pH}$ dependence thermal stability of a chymo- 
trypsin inhibitor from Schizolobium parahyba seeds. Biophys. J. 88, 3509-3517

Vogt, W. (1995) Oxidation of methionyl residues in proteins: tools, targets, and reversal. Free Radic. Biol. Med. 18, 93-105

Watanabe, K., Shinmoto, H., Kobori, M., Tsushida, T., Shinohara, K., Kanaeda, J., Yonekura, M. (1998) Stimulation of cell growth in the U-937 human myeloid cell line by honey royal jelly protein. Cytotechnology 26, 23-27
Winston, M.L. (1987) The biology of the honey bee. Harvard University Press, London

Wolschin, F., Amdam, G.V. (2007) Plasticity and robustness of protein patterns during reversible development in the honey bee (Apis mellifera). Anal. Bioanal. Chem. 389, 1095-1100

Yonekura, M., Watanabe, K., Saito, S., Tsutsumi, M., Shinohara, K., Kimura, Y., Takagi, S. (1992) The 65th Congress of the Japanese Biochemical Society, Fukuoka, Japan, Abstracts, Seikagaku, 64, p. 816 (in japanese) 